\title{
Financial analysis of Chir pine plantations for carbon offsets, timber and resin in Nepal
}

\begin{abstract}
B. $K C^{1}$ and G. A. Stainback ${ }^{2}$
A financial analysis was done for Chir pine (Pinus roxburghii) plantations that produce carbon offset payments, timber and resin in a community forest context in Nepal. Results indicate that the inclusion of carbon offset payments increases rotation age and land expectation value. The optimal rotation age is approximately 35 years without including carbon offset payments, while the rotation age can increase beyond 75 years with the inclusion of carbon offset payments. The substantial change in optimal rotation age also suggests that carbon offset payments will likely change the product mix produced from Chir pine plantations. Likewise, land expectation value increases significantly with carbon offset payments indicating that local communities could benefit from such payments. The results also indicate that different assumptions about the quantity of long term carbon storage (i.e. pickling rate) have a significant impact on rotation age and land expectation value.
\end{abstract}

Key words: Pinus roxbughii, land expectation value, carbon offset payment, resin

I $\mathrm{n}$ recent years, policy makers have been searching for different ways to mitigate the effects of rising Green House Gases (GHGs) concentration. Particular interest has been directed towards carbon stocks in forests which are the main terrestrial sinks for carbon (Balboa-Murias et al., 2006; Deng et al., 2011). Each cubic meter of wood stores approximately $200 \mathrm{~kg}$ of carbon in forests, and for every ton of carbon sequestered in forest biomass, 3.667 tons of $\mathrm{CO}_{2}$ are removed from the atmosphere (Krcmar et al., 2001). Globally, the quantity of carbon store in terrestrial ecosystem is 2477 billion tons, where soil and vegetation accounts for approximately $81 \%$, and $19 \%$, respectively (Ravindranath and Ostwald, 2008). Previous studies suggest that costs of carbon sequestration in forests are comparable to, and in some cases lower than, the costs of alternative mitigation and abatement approaches (Matthews et al., 2002). Their role in cost effective mitigation of atmospheric carbon dioxide has been widely recognized (Richards and Stokes, 2004; Sohngen and Brown, 2008; Nepal et al., 2012).

With the growth of community forests throughout the developing world, there is potential for them to play a significant role in sequestering and storing atmospheric carbon. There is growing

interests among policymakers and others in receiving carbon offset payments through carbon trading mechanisms as a means of generating income for local communities. Preliminary research findings from carbon monitoring surveys of selected community forests in Nepal suggest that carbon stocks are increasing at the rate of 2 to 5 tons per hectare per year (Dahal and Banskota, 2009). Thus, carbon offset payments could be another potential source of income to community forest users in addition to benefits from timber and resin. In this paper we have done a financial analysis of the management of Chir pine (Pinus roxburghii) forest plantations considering carbon offset payments, resin and timber using a Hartman model to estimate the optimal rotation age and land expectation value (LEV) at a range of carbon offset prices (in addition to timber and resin benefits). We have also estimated the impact of different assumptions of carbon emissions from the harvesting of wood products (or pickling rate) on the optimal rotation age and LEV. Finally, the impact that carbon offset payments would have on the optimal mix of forest products (timber and resin) from the plantation stand have also been estimated. The specific aim of this study is to estimate the magnitude of the impacts of carbon offset payments on Chir pine plantations grown in a community forest context in Nepal.

\footnotetext{
${ }^{1}$ Department of Parks, Recreation and Tourism Management, North Carolina State University Raleigh, N.C. 27695. E-mail: bkc@ncsu.edu
}

${ }^{2}$ Department of Forestry, University of Kentucky, Lexington, KY 40546 
Chir pine is a common coniferous species of the mid-hills regions $(900-1950 \mathrm{~m})$ of Nepal, and growing up to $2700 \mathrm{~m}$ (Jackson, 1994). It is found ranging from longitudes of $70^{\circ} \mathrm{E}$ to $93^{\circ} \mathrm{E}$ and latitudes of $26^{\circ} \mathrm{N}$ to $36^{\circ} \mathrm{N}$ (Ghildiyal et al., 2009). Naturally, it is distributed from Bhutan (only in drier areas), Northern India, Nepal (south of Tibet), Pakistan, and Afghanistan (Dogra, 1985; Yi and Raven, 1999; Gauli et al., 2009). It has standing volume of $6.3 \%$ of the total forest in Nepal (DFRS, 1999); proportionally the fourth highest total tree volume in the country. Establishing Chir pine on heavily degraded forest sites and grazing lands is an integral component of community forestry activities in the hill regions. Due to its high survival rate, it has proved to be a successful pioneer of most degraded sites (Mohns et al., 1988). In Nepal, Chir pine is the only species tapped for resin, and currently resin tapping is being done in around 35 out of 75 districts of Nepal. On average, one person can earn up to NRs. 30,000 $(\$ 400)$ in the eight months tapping period (Upadhyay, 2008). According to Resin Tapping
Guideline of Ministry of Forests and Soil Conservation (2007), resin tapping could be done when the diameter at breast height (DBH) reaches $30 \mathrm{~cm}$. Resin is used for manufacturing of rosin and turpentine. Rosin is used in manufacturing of adhesives, paper sizing agents, printing inks, detergents etc., while turpentine is used in disinfectants, cleaning agents, pharmaceutical preparations, perfumery industry and others (Coppen and Hone, 1995; Wang et al., 2006; Thakur, 2003).

\section{Materials and methods}

In this section we discuss how timber volume and the quantity of sequestered carbon were calculated. We also discuss how we used the Hartman (1976) model to estimate the optimal rotation age and economic returns from timber, resin and carbon offsets. This analysis makes use of thinning regime for a Chir pine plantation (Table 1).

\section{Timber and resin yield}

The portion of the tree greater than $20 \mathrm{~cm}$ in

Table 1: Chir pine plantation thinning regime used in the analysis

\begin{tabular}{cccc}
\hline Plantation Age (year) & Stems/ha & Stems/ha after thinning & Stems thinned/ha \\
\hline 5 & 1600 & 1600 & 0 \\
10 & 1600 & 1600 & 0 \\
15 & 1600 & 1400 & 200 \\
20 & 1400 & 1050 & 350 \\
25 & 1050 & 900 & 150 \\
30 & 900 & 800 & 100 \\
35 & 800 & 625 & 175 \\
40 & 625 & 500 & 125 \\
45 & 500 & 400 & 100 \\
50 & 400 & 300 & 100 \\
55 & 300 & 225 & 75 \\
60 & 225 & 190 & 35 \\
65 & 190 & 145 & 45 \\
70 & 145 & 145 & 0 \\
75 (last cut) & 145 & 0 & 145 \\
\hline
\end{tabular}

Source: DFRS, 2007 
diameter is considered big timber that is used in construction and similar purposes. Timber of this size class usually gets a higher price than smaller timber. Small timber was assumed to consist of the portion of the tree greater than $10 \mathrm{~cm}$ in diameter but less than $20 \mathrm{~cm}$ in diameter. The remainder of the tree volume was considered slash (not sold). To calculate the various timber product classes, first the whole tree volume was calculated followed by the volume up to $10 \mathrm{~cm}$ in diameter, and then subtracted from the whole tree volume. This gives the portion of tree stem that is considered slash. Next the volume of the stem up to $20 \mathrm{~cm}$ in diameter was calculated and subtracted from the volume up to $10 \mathrm{~cm}$. This gives the volumes of big and small timber. The volume of bark was subtracted from the volume of big and small timber and included as slash. All equations for volume calculations are based on the work of Sharma and Pukkala (1990) and are given in table 2. Height and DBH were taken from growth and yield data from 219 trees in Himachal Pradesh, India (Tewari, 1994) ${ }^{3}$. Because the DBH and height data were only given in 10 year increments, total tree, big timber, and small timber volumes were fitted to the following functional form, using nonlinear regression to obtain continuous yield functions:
Where $\mathrm{v}(\mathrm{t})$ is the volume of timber per hectare for a particular stand age, $t$ is the stand age in years and $\mathrm{a}, \mathrm{b}$, and $\mathrm{c}$ are parameters to be estimated. Resin yield was assumed to be $4.25 \mathrm{~kg}$ per tree per year and begin when DBH equals $30 \mathrm{~cm}$ (MFSC, 2007).

\section{Carbon offsets}

In general, carbon content is assumed to be $50 \%$ of dry matter (Negi et al., 2003; Lamlom and Savidge, 2003; Sharma and Singh, 2010). However, a Chir pine specific carbon content of $46.32 \%$, based on the work of Negi et al. (2003), was used in this analysis. The dry density of Chir pine is 0.497 metric tons per cubic meter (Chaturvedi and Khanna, 1982). Thus the carbon per cubic meter of Chir pine can be estimated by multiplying the volume (in cubic meters) by 0.2302 (0.497 x 0.4632). Since, $\mathrm{CO}_{2}$ equivalents are traded in the market, not carbon, we converted the amount of carbon into $\mathrm{CO}_{2}$ equivalents by multiplying by 3.67 . Hence, all the carbon benefits are presented as $\mathrm{CO}_{2}$ equivalents.

\section{Land expectation value (LEV) calculation}

The present value of carbon was calculated using equation 2.

$$
v(t)=a t^{b} e^{-c t .}
$$

Table 2: Equations used for timber calculations (Sharma and Pukkala, 1990)

\begin{tabular}{|c|c|c|}
\hline S.No & Equations & Parameter definition \\
\hline 1. Volume & $\begin{array}{l}\left.\operatorname{In}(v)=a(-2.9770)+b(1.9235) * \operatorname{In}(d)+c^{*} 1.0019\right) * \\
\operatorname{In}(h)\end{array}$ & $\begin{array}{l}\mathrm{V}=\text { total stem vol. with bark }\left(\mathrm{dm}^{3}\right) \\
\mathrm{d}=\text { diameter }(\mathrm{cm}) \\
\mathrm{h}=\text { height }(\mathrm{m})\end{array}$ \\
\hline $\begin{array}{l}\text { 2. Proportion of tree top } \\
\text { (beyond } 10 \mathrm{~cm} \text { ) }\end{array}$ & $\operatorname{In}\left(V_{1} / V\right)=a(6.2696)+b(-2.8252) * \operatorname{In}(d)$ & $\begin{array}{l}\mathrm{V}_{1}=\text { over bark vol.of tree top } \\
\mathrm{V}=\text { total over bark stem vol. }\end{array}$ \\
\hline $\begin{array}{l}\text { 3. Proportion of timber } \\
\text { beyond } 20 \mathrm{~cm} \text { dia.but }\end{array}$ & $\operatorname{In}\left(\mathrm{V}_{2} / \mathrm{V}_{\mathrm{t}}\right)=\mathrm{a}(8.5662)+\mathrm{b}(-3.0486) * \operatorname{In}(\mathrm{d})$ & $\begin{array}{l}\mathrm{V}_{2}=\text { over bark vol. of the portion of } \\
\text { timber beyond } 20 \mathrm{~cm} \text { in dia. }\end{array}$ \\
\hline$>10 \mathrm{~cm}$ in dia. & & $\begin{array}{l}\text { but }>10 \mathrm{~cm} \text { in dia. } \\
\mathrm{V}_{\mathrm{t}}=\text { total over bark vol. up to } \\
10 \mathrm{~cm} \text { in dia. }\end{array}$ \\
\hline $\begin{array}{l}\text { 4. Proportion of bark in } \\
\text { timber }>10 \mathrm{~cm} \text { in dia. }\end{array}$ & $\operatorname{In}\left(\mathrm{P}_{\mathrm{b}}\right)=\mathrm{a}(1.1763)+\mathrm{b}(-0.6997)^{*} \operatorname{In}(\mathrm{d})$ & $\mathrm{P}_{\mathrm{b}}=$ bark proportion \\
\hline $\begin{array}{l}\text { 5. Proportion of bark in } \\
\text { timber }>20 \mathrm{~cm} \text { in dia. }\end{array}$ & $\operatorname{In}\left(\mathrm{P}_{\mathrm{b}}\right)=\mathrm{a}(1.2535)+\mathrm{b}(-0.7194) * \operatorname{In}(\mathrm{d})$ & $\mathrm{P}_{\mathrm{b}}=$ bark proportion \\
\hline
\end{tabular}

${ }^{3}$ The growth and yield data used in this analysis do not allow for variation in plant density or site quality. Some publications on Pinus roxburghii by Applegate et al. (1988) and Gilmour et al. (1990) provide some data in this regard. Likewise, a working paper by Rautiainen (1991) also provides some information regarding stocking, diameter and height for specific ages of plantations of Pinus roxburghii in the Nepalese context. However, they do not provide sufficient information to estimate yields. Therefore, data from Tewari (1994) was used in this study. 
$P V_{C}=\sum_{0}^{\mathrm{t}} P C \alpha\{\mathrm{v}(\mathrm{t})-\mathrm{v}(\mathrm{t}-1)\} e^{-r t}-P c \alpha(1-\beta) \mathrm{v}(\mathrm{t}) e^{-r t}$.

Where, PVC is the present value of carbon over one rotation or harvest cycle in $\$ /$ hectare, $\mathrm{PC}$ is the price of carbon ( $\$ / \mathrm{CO}_{2}$ equivalent), $\alpha$ represents the metric tons of carbon per cubic meter of tree biomass, $v(t)$ is the volume of timber calculated at a particular stand age, $\beta$ is the pickling rate or the amount of carbon sequestered long-term after harvest, and $\mathrm{r}$ is the discount rate. We did a sensitivity analysis of different carbon prices of $\$ 0, \$ 2, \$ 5, \$ 10, \$ 25$ and $\$ 50$. The discount rate is assumed to be $10 \%$. This discount rate is based on a literature review as well as personal contacts with Forest Officers at Department of Forest, Kathmandu, Nepal. The analysis was done with different values of the pickling rate $\beta(0,1 / 2$, and 1) for big timber. A pickling rate of 0 indicates that all the carbon sequestered during tree growth will be emitted back into the atmosphere through decay or burning soon after harvest. Likewise, a pickling rate of 0.5 indicates that $50 \%$ of the sequestered carbon will be emitted back into the atmosphere soon after harvest and $50 \%$ will remain sequestered. A pickling rate of one indicates that all sequestered carbon remains sequestered after harvest. For small timber and slash the pickling rate was assumed to be 0 .

The present value of timber was calculated by using equation 3 :

$$
P V_{t}=\operatorname{Prv}(t) e^{-r t}
$$

Where, PVT is the present value of timber in $\$ /$ hectare, PT is the price of timber in $\$ /$ cubic meter, $r$ is the discount rate, and $t$ equals the stand age in years. We use a timber price of 50 (approximately \$0.625) Nepalese Rupees per cubic foot for big timber and $50 \%$ of this price for small timber (GoN, 2005). Likewise, the present value of resin was calculated by using equation 4:

$$
P V R=\sum_{0}^{t} P R V r(t) e^{-r t}
$$

Where $P V_{R}$ is the present value of resin in $\$ /$ hectare, $P_{R}$ is price of resin in $\$ /$ ton, $\operatorname{vr}(t)$ is the volume of resin calculated at a particular age $(\mathrm{t}), \mathrm{r}$ is discount rate, and $t$ is the stand age in years. We are using resin price of 6 (approximately \$0.075) Nepalese Rupees per $\mathrm{kg}$ for this analysis (GoN, 2005). The cost of resin tapping is assumed to be borne by resin traders so are not included in the financial analysis.

Establishment cost (EC) is a cost associated with plantation in the plantation year which is assumed to be NRs. 3200/ha (approximately \$43) based on personal communication with Forest Officers at Department of Forest. We assume forest management and thinning costs to be zero because it will be carried out with community labor or community participation. All of the harvesting costs are assumed to be paid by the timber buyer or timber harvesting company and therefore considered to be external to the community.

Finally, LEV was calculated using present value of carbon, timber and resin along with establishment cost using equation 5:

$\mathrm{LEV}=(\mathrm{PVc}+\mathrm{PVT}+\mathrm{PVR}-\mathrm{EC}) /\left(1-\mathrm{e}^{-\mathrm{rt}}\right)$

Where, LEV is the land expectation value in $\$ /$ hectare assuming the forest stand is management in perpetuity for timber, carbon and resin. PVc equals the present value of carbon in $\$ /$ hectare over one harvest cycle, $\mathrm{PV}_{\mathrm{T}}$ equals the present value of timber in $\$ /$ hectare over one harvest cycle, $\mathrm{PV}_{\mathrm{R}}$ is the present value of resin in $\$ /$ hectare over one harvest cycle, $r$ is the discount rate and $t$ equals the stand age in years. LEV results are presented in US dollars based on the exchange rate of $\$ 1=$ NRs. 75 .

\section{Results and discussion}

\section{Land expectation value ( $\mathrm{LEV})$}

Figure 1 shows the relationship between carbon prices and LEV. The LEV increases significantly with an increase in carbon price. With a carbon price of 0 (i.e. only with timber and resin benefit), LEV is $\$ 35.25$ per hectare. As soon as carbon price increases from $\$ 2$ to $\$ 50, \mathrm{LEV}$ increases from $\$ 51.18, \$ 52.84$, and $\$ 54.49$ to $\$ 503.63$, $\$ 538.19$, and $\$ 572.75$ at different pickling rates $(\beta)$ of $0,0.5$, and 1 , respectively. Therefore, there would be a substantial increase in LEV with the increase in carbon prices regardless of the assumption made about carbon emissions at harvest. Similar results were observed (i.e. increased LEV with inclusion of carbon benefit) by Andrew Stainback and Alavalapati (2002) and Dwivedi et al. (2009). LEV is higher at larger pickling rates due to emission costs (i.e. higher 
emission cost when pickling rate of 0 , lower emission cost with pickling rate of 0.5 , and no emission cost when pickling rate of 1) at the time of harvest.

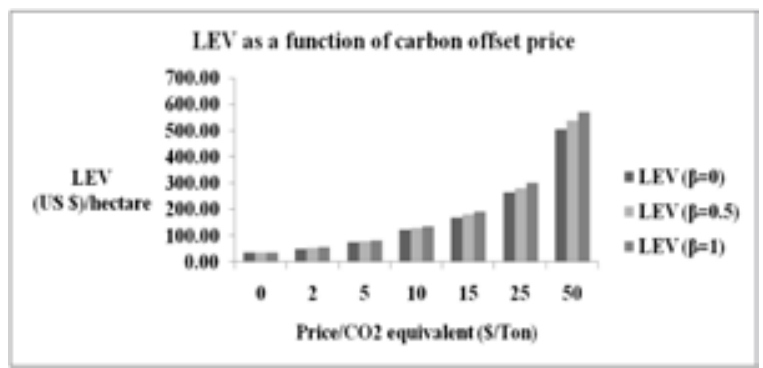

Fig. 1: LEV (US \$) at different prices of carbon and emission assumptions $(\beta)$ at harvest

\section{Optimal rotation age}

Figure 2 shows the overall results for optimal rotation as a function of carbon offset price at three different pickling rates. Due to the uncertainty of carbon markets and future carbon offset prices, we considered a wide range of carbon prices from $\$ 2$ to $\$ 50$. All the results assume a discount rate of $10 \%$. The optimal rotation age is 35 years when there is no income from carbon. When the price of carbon is $\$ 2$ per ton and above, the optimal rotation age increases. Therefore the price of carbon has significant effect on the optimal rotation age as well as LEV. Several other studies also concluded that optimal rotation age increases with the inclusion of carbon offset payments (Romero et al., 1998; Andrew Stainback and Alavalapati, 2002; Kooten et al., 1995; Price and Willis, 2011). At a pickling rate of 0 , rotation age will be higher than when pickling rate is 0.5 or 1 . This result is more pronounced at higher carbon prices. ${ }^{4}$ A pickling rate of 0 means that all the

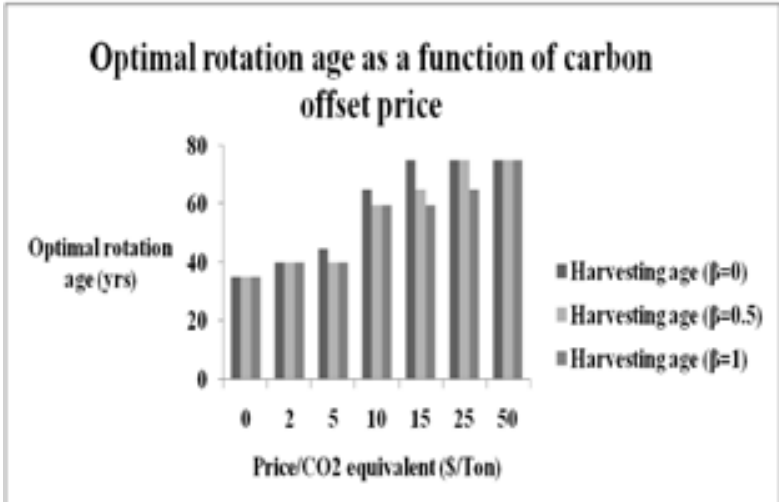

Fig. 2: Optimal rotation age at different prices of carbon and emission assumptions $(\beta)$ at harvest

\footnotetext{
${ }^{4}$ When the carbon price is $\$ 25$ per ton then the rotation age is at or above the model maximum of 75 years at all pickling rates.
}

carbon sequestered will be emitted back into the atmosphere when harvested. With this pickling rate, there would be higher emission costs at the time of harvest, which creates an incentive to delay harvest.

In addition, carbon payments increase big timber supply and resin production due to extending the rotation age. However as the carbon price increases the supply of small timber declines. When the rotation age is increased due to carbon payments, then there are two effects on timber supply. As the trees age due to a longer rotation age, more timber is produced. However the stand is also harvested less frequently due to the longer rotation age. To account for both of these impacts, timber supply is calculated assuming a regulated forest by dividing the volume of timber produced at the end of the rotation by the length (years) of the rotation. Figure 3 shows the amount of big timber and small timber volume produced at different carbon prices and pickling rates. Only trees with a diameter of $30 \mathrm{~cm} \mathrm{DBH}$ are considered capable of producing resin. Thus, as the rotation age is lengthened resin production increases.

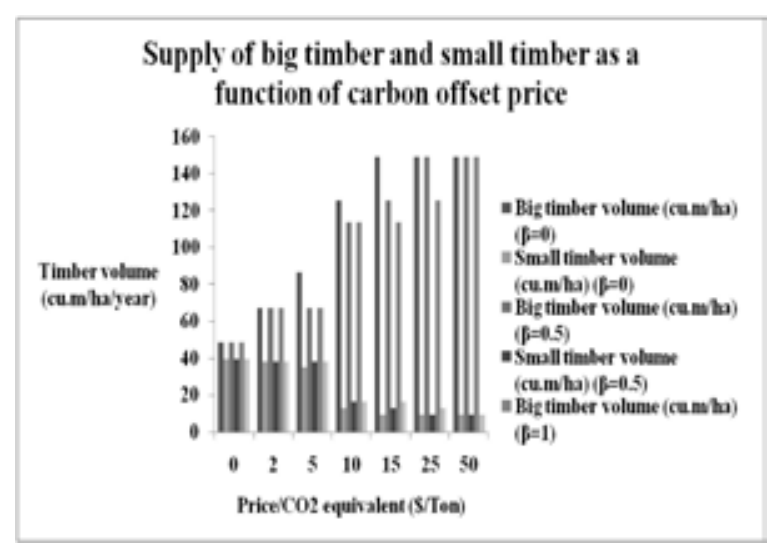

Fig. 3: Big timber volume and small timber volume at different prices of carbon and emission assumptions ( $\beta$ ) at harvest

\section{Conclusion}

Chir pine is a common forest type found in the mid-hills region of Nepal managed both by communities and private enterprises. In this study we modeled how carbon offset payments would impact the optimal rotation age and LEV of Chir pine. In the community forestry context, where forests are managed for big timber, small timber and resin, carbon offset payments substantially increase the optimal rotation age and the LEV. 
The increase in LEV could bring much needed cash income to local communities in the region. The increase in the rotation age would increase the amount of big timber and resin and decrease the amount of small timber produced from each harvest. Since timber and resin is a primary source of income from Chir pine plantation, carbon offset payment additionally could substantially increase economic benefit to the community. The increase in cash income due to carbon offset payment could also allow local communities to engage in more intensive forest management which would potentially bring additional benefits.

Future studies could investigate the impact that carbon offset payments would have on forest management variables other than rotation age (e.g. spacing and alternative thinning regimes). This study only considered forest management at the stand level. However, the substantial increase in LEV due to carbon offset payments could induce local communities to plant and manage forest on more marginal land. Thus, economic studies that included impacts on the extensive margin could be useful. Finally, due to limited data, the growth and yield information utilized in this study comes from regions in India that have similar growing conditions to those in the mid-hills region of Nepal. Growth and yield information specific to the midhills region of Nepal could improve future studies.

\section{Acknowledgements}

The authors would like to acknowledge the University of Kentucky for funding this study. Also, we would like to thank the Forest Officers at the Department of Forest and Department of Forest Research and Survey for providing information.

\section{References}

Andrew Stainback, G., and Alavalapati, J. R. R. 2002. Economic analysis of slash pine forest carbon sequestration in the southern U. S. Journal of Forest Economics 8 (2): 105-117.

Applegate, G. B., Gilmour, D. A., and Mohns, B. 1988. Biomass and productivity estimations for community forest management: a case study from the hills of Nepal - I. Biomass and productivity of Chir pine (Pinus roxburghii Sargent) plantations. Biomass 17 (2): 115-136.

Balboa-Murias, M. Á., Rodríguez-Soalleiro, R., Merino, A., and Álvarez-González, J. G. 2006. Temporal variations and distribution of carbon stocks in aboveground biomass of radiata pine and maritime pine pure stands under different silvicultural alternatives. Forest Ecology and Management 237 (1-3): 29-38.

Chaturvedi, A. N., and Khanna, L. S. 1982. Forest Mensuration. International Book Distributors, Dehradun, India.

Coppen, J. J. W., and Hone, G. A. 1995. Gum Naval Stores: Turpentine and Rosin from Pine Resin. Natural Resources Institute, FAO, Rome, Italy.

Dahal, N., and Banskota, K. 2009. Cultivating REDD in Nepal's community forestry: A discourse for capitalizing on potential? Journal of Forest and Livelihood 8 (1): 41-50.

Deng, S., Shi, Y., Jin, Y., and Wang, L. 2011. A GIS-based approach for quantifying and mapping carbon sink and stock values of forest ecosystem: A case study. Energy Procedia, 5 (0): 1535-1545.

DFRS.1999. Forest Resources of Nepal (1987-1998). Publication no.47, .Department of Forest Research and Survey, Kathmandu, Nepal.

DFRS. 2007. The Thinning Guidelines for Plantation Forest of Pinus patula and Pinus roxburghii in Nepal. Minsitry of Forests and Soil Conservation, Department of Forest Research and Survey, Kathmandu, Nepal.

Dogra, P. D. 1985. Conifers of India and their wild gene resources in relation to tree breeding. Indian Forester 111 (11): 935-955.

Dwivedi, P., Alavalapati, J. R. R., Susaeta, A., and Stainback, A. 2009. Impact of carbon value on the profitability of slash pine plantations in the southern United States: an integrated life cycle and Faustmann analysis. Canadian Journal of Forest Research 39 (5): 990-1000. 
Gauli, A., Gailing, O., Stefenon, V., and Finkeldey, R. 2009. Genetic similarity of natural populations and plantations of Pinus patula and Pinus roxburghii Sarg. in Nepal. Annals of Forest Science 66 (7): 703-703.

Ghildiyal, S. K., Sharma, C. M., and Gairola, S. 2009. Additive genetic variation in seedling growth and biomass of fourteen Pinus roxburghii provenances from Garhwal Himalaya. Indian Journal of Science and Technology 2 (1): 37-45.

Gilmour, D. A., King, G. C., Applegate, G. B., andMohns, B. 1990. Silviculture of plantation forest in central Nepal to maximise community benefits. Forest Ecology and Management 32 (2-4): 173-186.

GoN. 2005. Forest Regulation 1995 (3rd amendment). Ministry of Forests and Soil Conservation, Kathmandu, Nepal.

Hartman, R. (1976). The harvesting decision when a standing forest has value. Economic Inquiry 14 (1): 52-58.

Jackson, J. K.(1994. Manual of Afforestation in Nepal. Forest Research and Survey Centre, Babarmahal, Kathmandu, Nepal.

Kooten, G. C. v., Binkley, C. S., and Delcourt, G. 1995. Effect of carbon taxes and subsidies on baoptimal forest rotation age and supply of carbon services. AmericanJournal of Agricultural Economics 77 (2): 365-374.

Krcmar, E., Stennes, B., Cornelis van Kooten, G., and Vertinsky, I. 2001. Carbon sequestration and land management under uncertainty. European Journal of Operational Research 135(3): 616-629.

Lamlom, S. H., and Savidge, R. A. 2003. A reassessment of carbon content in wood: variation within and between 41 North American species. Biomass and Bioenerg, 25 (4): 381-88.

Matthews, S., O Connor, R., and Plantinga, A. J. 2002. Quantifying the impacts on biodiversity of policies for carbon sequestration in forests. Ecological Economics 40 (1): 71-87.

MFSC. 2007. Resin Tapping Guideline. Ministry of Forests and Soil Conservation,
Kathmandu, Nepal.

Mohns, B., Applegate, G. B., and Gilmour, D. A. 1988. Biomass and productivity estimations for community forest management: A case study from the hills of Nepal - II. Dry matter production in mixed young stands of chir pine (Pinus roxburghii) and broad-leaved species. Biomass 17 (3): 165-184.

Negi, J. D. S., Manhas, R. K., and Chauhan, P. S. 2003. Carbon allocation in different components of some tree species of India: A new approach for carbon estimation. Current Science 85 (11): 1528-1531.

Nepal, P., Grala, R. K., and Grebner, D. L. 2012. Financial feasibility of increasing carbon sequestration in harvested wood products in Mississippi. Forest Policy and Economics 14 (1): 99-106.

Price, C., and Willis, R. 2011. The multiple effects of carbon values on optimal rotation. Journal of Forest Economics 17 (3): 298-306.

Rautiainen, O. 1991. Management of Young Chir pine Stands: A Case Study in Lele village, Lalitpur District. Forest Management and Utilization Division/FMUDP Project, Kathmandu, Nepal.

Ravindranath, N. H. and Ostwald, M. 2008. Carbon Inventory Methods: Handbook for Greenhouse Gas Inventory. Carbon Mitigation and Roundwood Production Projects: Springer London, Limited.

Richards, K. R., and Stokes, C. 2004. A review of forest carbon sequestration cost studies: A dozen years of research. Climatic Change 63: $1-48$.

Romero, C., Ros, V., Rios, V., Daz-Balteiro, L., and Diaz-Balteiro, L. 1998. Optimal forest rotation age when carbon captured is considered: Theory and Applications. The Journal of the Operational Research Society 49 (2): 121-131.

Sharma, D., and Singh, M. 2010. Assessing the carbon sequestration potential of subtropical pine forest in north-western Himalayas - A GIS approach. Journal of the Indian Society of Remote Sensing 38 (2): 247-253. 
Sharma, E. R., and Pukkala, T. 1990. Volume Equations and Biomass Prediction of Forest Trees of Nepal. Publication No. 47, Ministry of Forests and Soil Conservation, Forest Survey and Statistics Division, Babar Mahal, Kathmandu, Nepal.

Sohngen, B., and Brown, S. 2008. Extending timber rotations: carbon and cost implications. Climate Policy 8 (5): 435-451.

Tewari, D. N. 1994. A Monograph on Chir pine (Pinus roxburghii Sarg.). International Book Distributors, Rajpur Road, Dehradun, India.

Thakur, R. B. 2003. A Compendium of Tree Species of Nepal. Sarvottam Offset
Printing Press (P.) Ltd. Putalisadak, Kathmandu, Nepal.

Upadhyay, M. 2008. A Term Paper on Economic Analysis of Resin Tapping (Unpublished). Institute of Forestry, Pokhara, Nepal.

Wang, Z., Calderon, M. M., and Carandang, M. G. 2006. Effects of resin tapping on optimal rotation age of pine plantation. Journal of Forest Economics, 11(4): 245-260.

Yi, W. Z., and Raven, P. H. 1999. Flora of China, Vol. 4. Science Press, St. Louis, Missouri Botanical Garden, Beijing, China. 